\title{
PERFORMANCE EVALUATION OF FARM TRACTOR USING VARIABLE WEIGHTS ON REAR WHEELS DURING PLOUGHING AND SOWING OPERATIONS
}

\author{
H. A. Jebur' ; M. M. Mostafa ${ }^{2}$; E. A. El-Sahhar ${ }^{2}$; M. A. El-Attar \\ M. A. Elnono ${ }^{2}$
}

\section{ABSTRACT}

The general objectives of this study were to investigate the performance characteristics of a farm tractor during ploughing (chisel plough) and sowing (seed drill) using variable weights from (0 to $500 \mathrm{~kg}$ ) on the rear tractor wheels, and different traveling speeds from $(2.78$ to $5.68 \mathrm{~km} / \mathrm{h})$. the ploughing depths were $(15-20 \mathrm{~cm})$, and the average moisture content was $(20.15 \%)$. The soil texture was found to be a (Silty clay). The rear tier sizes of the tractor and inflation pressure were 16.9/14-38 and 150 $k P a$, respectively. The study was concentrated on the rate of fuel consumption, required power, specific energy, drawbar pull, tractor wheel slippage, tractive efficiency, effective field capacity and field efficiency. The obtained results, for the range of tests, showed that the use of $500 \mathrm{~kg}$ weight on the tractor rear wheel at $3.1 \mathrm{~km} / \mathrm{h}$ traveling speed produced the highest value $(74.4 \%)$ of tractive efficiency, in case of chisel plough operation, and (in the mean time) the wheel slippage, filed efficiency, fuel consumption, required power, specific energy were 7.46 $\%, 80.22 \%, 15.11 \mathrm{l} / \mathrm{h}, 46.58 \mathrm{~kW}$, and $43.13 \mathrm{~kW} . \mathrm{h} / \mathrm{fed}$, respectively. While in case of seed drill operation, the use of $500 \mathrm{~kg}$ weight at $3.07 \mathrm{~km} / \mathrm{h}$ traveling speed produced the highest value (57.7\%) of tractive efficiency, and the wheel slippage, filed efficiency, fuel consumption, required power, specific energy were $2.84 \%, 76.55 \%, 4.63 \mathrm{l} / \mathrm{h}, 14.27 \mathrm{~kW}$, and $8.25 \mathrm{~kW} . \mathrm{h} / \mathrm{fed}$, respectively. In general, the traveling speed and the weight

${ }^{1}$ Graduate student, Agric. Eng, Dept, Faculty of Agric., Ain shams Univ.

2 Agric. Eng. Dept., Faculty of Agric., Ain shams Univ.

${ }^{3}$ Senior Researcher, Agric. Eng. Res. Institute. 
on the rear tractor wheels were the most important factors that affecting the drawbar pull and the specific energy.

Key words: Tractor, Energy, Chisel plough, Seed drill, Weight, Power

\section{INTRODUCTION}

Tractor is the basic unit power at the farm. It is considered the hub
of agricultural mechanization as it can be used to operate the
agricultural implements and its power on farm will continue to be an absolute necessity for increasing agricultural production. It is useful for field work, materials handling, and processing operation on farm.

The amount of energy consumed during chisel plough and seed drill operations depend on soil and operating conditions. So that it must increase operation efficiency of farm tractor. Abbaspour-Gilandeh et. al. (2007) reported that the agricultural tractors consume about 20 percentage of total energy, required for a farm. Therefore optimizing performance of agricultural tractors could bring energy losses down. Lyasko M.I. (2010) Indicated that the soil conditions significantly affect on tractive performance of off-road wheeled and tracked vehicles. Mehta et al (2010) Indicated that the tractor is used for various field operations. Therefore, it is recommended that the field operations which are the most time sensitive or that require the highest power should be taken into consideration for determining the power of tractor. Sahay and Tewari (2004) mentioned that the satisfactory performance of the tractorimplement system is dependent upon the stability of the operation, power of the engine and traction developed. Mostafa et. al. (1993) indicated that the slippage resistance power increases as the traveling speed increases. The may be due to the variation in the different between traveling speed without load and effective traveling speed under load. The fuel consumption increases by increase of traveling speed, where the fuel consumption increased from $13.65 \mathrm{l} / \mathrm{h}$ to $14.5 \mathrm{l} / \mathrm{hr}$ by increasing traveling speed from 4.38 to $4.75 \mathrm{~km} / \mathrm{hr}$. The fuel consumption was measured during the field experiments.

El-Kewey (1992) mentioned that, the rolling resistance is a factor which is not obvious to a tractor operator but it is important because it represents a significant power loss which reduces the rate of work. Also, power lost 
in overcoming rolling resistance is absorbed in deforming the soil, so the higher rolling resistance the greater is the likelihood of soil damage by compaction.

El-Ashry et. al. (2003) carried out field experiments to evaluate the tractive performance at different levels of ballast conditions $(0,60$ and 90 $\mathrm{kg}$ ) in ploughed and unploughed soils. They concluded that the tractive efficiency increased up to a certain value of ballast conditions (from $0 \mathrm{~kg}$ to $60 \mathrm{~kg}$ ) beyond which it decreased with an increase in ballast conditions (from $60 \mathrm{~kg}$ to $90 \mathrm{~kg}$ ) in tilled and untilled soil conditions.

Narang and Vershney (2006) summarized the results as the following main points: 1- The wheel slip increased with the increase in draft of the tractor; 2- The drawbar power increased by 0.170 and $0.139 \mathrm{~kW}$ at rated speed and three fourth rated speed of two wheel tractor, with the mounting of $40 \mathrm{~kg}$ wheel ballast; and 3- The fuel consumption increased by about $19 \%$ with the mounting of $40 \mathrm{~kg}$ wheel ballast.

Younis et al. (2010) indicated that the performance of drawbar test has been measured the following data: traveling speed, fuel consumption, the equivalent traveling speed and drawbar pull. The maximum drawbar power affected by drawbar pull as showed $(62.31$ and $62.58 \mathrm{~kW})$ at highest traveling speed of (6.72 and $7.7 \mathrm{~km} / \mathrm{hr}$ ), respectively. Dahab and Al-Hashem (2002) studied the effect of tractor speed working on clay loam soil on drawbar pull. The results showed that the increases in tractor speed had a highly effect on drawbar pull. The increases in tractor speed from $5 \mathrm{~km} / \mathrm{h}$ to $9 \mathrm{~km} / \mathrm{h}$ increased pull by $39 \%$ for tractor had $53.2 \mathrm{~kW}$ rated power. Abu-Hamdeh (1998) reported that the operation of farm tractors near their maximum tractive efficiency increases tractor productive output and results in fuel savings. However, operating condition in the field affected on performance of tractors, fuel consumption and physical properties of soil. Bashford (1984) said that the tractive efficiency is a parameter that defines the percentage of tractor axle power that is transformed into drawbar power. It is influenced by the traction ratio, rolling resistance, and the wheel slip. Jain and Philip (2003) mentioned that the power requirement of a tractor for different field operations can be calculated after getting the preliminary details 
regarding land holding, total available working time, soil conditions and type of operations.

The present study aims to investigate, test and evaluate the relationships between power, weight, drawbar pull and traveling speed of farm tractor during ploughing and sowing operations using chisel plough and seed drill, respectively, with the use of different weights on the rear tractor wheels and different traveling speeds through the following specific objectives:

1. Determination the wheel slippage.

2. Determination the drawbar pull.

3. Determination the tractive efficiency.

4. Determination the fuel consumption, required power and specific energy.

5. Determination the effective field capacity and field efficiency

\section{MATERIALS AND METHODS}

The experimental work was carried out in El-Gemmaiza Agriculture Research Station, El-Garbia Governorate Egypt during the summer of 2012. The soil type was Silt clay and the average soil moisture content during working time was $20.15 \%$ (dry basis), at ploughing depths (15-20) $\mathrm{cm}$. The variable weights (from 0 to $500 \mathrm{~kg}$ ) on the rear tractor wheels and travailing speeds (from 2.78 to $5.68 \mathrm{~km} / \mathrm{h}$ ) were used. The mechanical analysis of the soil is shown in table (1).

Table (1) Mechanical analysis of the experimental soil.

\begin{tabular}{|l|l|l|l|l|c|}
\hline \multicolumn{4}{|c|}{ Soil fraction } & CaCo3, \% & $\begin{array}{c}\text { Soil } \\
\text { textural } \\
\text { class }\end{array}$ \\
\hline Clay, \% & Silt, $\%$ & $\begin{array}{l}\text { Fin sand } \\
\%\end{array}$ & $\begin{array}{l}\text { Coarse } \\
\text { sand, } \%\end{array}$ & & Silt clay \\
\hline 46.35 & 35.15 & 17.30 & 1.20 & 2.62 & \\
\hline
\end{tabular}

The following materials and methods were used

\section{A- descriptions of tractors and implements :}

\section{1- Tractors:}

Two tractors (New Holland 110-90) were used. The specifications of the used tractors are:

$\begin{array}{ll}\text { Type } & \text { New Holland } \\ \text { Engine HP at R.P.M } & 90 \text { at } 2500 \\ \text { Engine type } & \text { IVECO }\end{array}$


Fuel type and No. of cylinders

Bore and stroke (mm)

P.T.O. - (rpm)

Tire size front, rear

Capacity $\left(\mathrm{cm}^{3}\right)$

Cooling system

Weight $(\mathrm{kg})$
Diesel, 6 cylinders

$104 \times 132$

540-2200

7.50-20, 16.9/14-38

6728

Water

4930

\section{2- Chisel plough:}

The specifications of the Chisel plough are:

A local manufactured RAU "Behera Co", rear mounted, Share spacing $(25 \mathrm{~cm})$, Total width $(175 \mathrm{~cm})$, Mass $(500 \mathrm{~kg})$, Without wheel depth control and With 7 tines arranged in two rows as 3 and 4 from front to rear.

\section{3- Seed drill:}

The specifications of the seed drill were:-

$\begin{array}{ll}\text { Type } & \text { Tye (USA) } \\ \text { drive system } & \text { Rubber wheels. } \\ \text { number of rows } & 20 \\ \text { Length }(\mathrm{m}) & 1.23 \\ \text { Width }(\mathrm{m}) & 3.0 \\ \text { Height }(\mathrm{m}) & 1.15 \\ \text { Weight }(\mathrm{kg}) & 500 \\ \text { Seed wt. }(\mathrm{kg}) & 200 \\ \text { Distance between rows }(\mathrm{cm}) & 0-15\end{array}$

\section{B- Measuring instruments:}

1- Spring dynamometer; 2- Fuel consumption apparatus; 3- $50 \mathrm{~m}$ tape; and 4- Stop watch.

\section{C- Parameter measurement and determination}

\section{1- Soil moisture content (MC)}

Soil moisture content was determined by using the standard oven methods. Soil samples were taken at depths (from 0 to $20 \mathrm{~cm}$ ) by screw ouger. They were weighted, and then dried at $105{ }^{\circ} \mathrm{C}$ for $24 \mathrm{~h}$ in electric oven. The moisture content was calculated according to (Black et. al. 1965) as:

$$
M C=\left(\frac{W_{W}-W_{d}}{W_{d}}\right) \times 100
$$


Where

$\mathrm{MC}=$ Soil moisture content (dry basis) \%

$\mathrm{W}_{\mathrm{w}}=$ wet soil mass, $\mathrm{gm}$

$\mathrm{W}_{\mathrm{d}}=$ dry soil mass, gm

\section{2- Traveling speed (TS)}

It was calculated as follows

Where

$$
T S=\frac{x}{t} \times 3.6
$$

$\mathrm{TS}=$ traveling speed, $\mathrm{km} / \mathrm{h}$

$\mathrm{x}=$ traveling measured distance, $\mathrm{m}$

$\mathrm{t}=$ traveling measured time, $\mathrm{s}$

\section{3- Fuel consumption (FC)}

Fuel consumption per unit time was determined by measuring the volume of consumed fuel during ploughing or sowing time. It was calculated as follows:

Where

$$
F C=\left(\frac{V}{t}\right) \times 3.6
$$

FC : rate of fuel consumption, $1 / \mathrm{h}$

$\mathrm{V} \quad$ : volume of consumed fuel, $\mathrm{cm}^{3}$

$\mathrm{T}$ : time, $\mathrm{s}$

\section{4- Tractive force:}

The tractive force of the tractor was measured by using a spring dynamometer and two tractors. One of the two tractors was towed by the other. The rear (towed) tractor (Newholand 110-90) is used as an implement carrier whereas the front one (Newholand 110-90) is, thus, used as a prime mover. A horizontal chain with the spring dynamometer linked the two tractors. The rear tractor which pulled the implement (chisel plough or seed drill) is being in neutral gear but with implement in the operating position. The tractive force was recorded in the measure distance of $50 \mathrm{~m}$ as well as the time taken to transverse it. On the same field the implement was lifted out of the ground and the rear tractor was pulled to record the rolling resistance (A), then the drawbar pull (B) was calculated as follow:

During the operation the following measurement were obtained: 
$\mathrm{A}=$ rolling resistance for the working unit (tractor + plough or seed drill).

$\mathrm{B}=$ the recording pull by using plough or seed drill.

Net drawbar pull $(\mathrm{kN})=$ Tractive force $(\mathrm{kN})$ - Rolling resistance $(\mathrm{kN})$

5- Wheel slip (S):

The slippage percentage was measured by using the following formula:

Where

$$
S=\frac{T S_{1}-T S_{2}}{T S_{1}} \times 100
$$

S : wheel slip, \%

$\mathrm{TS}_{1} \quad$ : traveling speed without load $\mathrm{km} / \mathrm{h}$.

$\mathrm{TS}_{2} \quad$ : traveling speed with load $\mathrm{km} / \mathrm{h}$.

\section{6- Drawbar power $\left(\mathbf{P}_{\mathrm{db}}\right)$ :}

Drawbar Power $(\mathrm{kW})=$ Net drawbar pull $(\mathrm{kN}) \times$ traveling speed $(\mathrm{km} / \mathrm{h}) / 3.6$

\section{7-Power consumed by rolling resistance $\left(\mathbf{P}_{\mathrm{rr}}\right)$ :}

Rolling resistance power $(\mathrm{kW})=$ rolling resistance $(\mathrm{kN}) \times$ traveling speed $(\mathrm{km} / \mathrm{h}) / 3.6$

8- Power consumed by slip $\left(\mathbf{P}_{\mathrm{sl}}\right)$ :

$$
P_{s l}=\left[P_{d b}+P_{r r}\right] \times \frac{S}{100-S}
$$

(Al-Ashry 1994 and El-Khatib 1998)

Where:

$\mathrm{P}_{\mathrm{sl}} \quad=$ Power consumed by slip $(\mathrm{kW})$

$\mathrm{P}_{\mathrm{db}} \quad=$ Drawbar power $(\mathrm{kW})$

$\mathrm{P}_{\mathrm{rr}} \quad=$ rolling resistance power $(\mathrm{kW})$

$\mathrm{S} \quad=$ Slip in percent $(\%)$.

9- Tractive efficiency (TE):

Tractive efficiency is defined as:

$T E=\frac{\text { Output Power }}{\text { Input power }} \times 100 \Rightarrow \frac{\text { Drawbar Power }}{\text { Axle power }} \times 100$

(Barger et. al. 1963, and Sharma and Mukesh 2010)

where $\mathrm{TE}=$ tractive efficiency $\%$

\section{$\underline{10-\text { Effective Field capacity }\left(E_{\text {fc }}\right)}$}

Theoretical field capacity $=\frac{\text { Machine } \operatorname{width}(\mathrm{m}) \times \operatorname{speed}(\mathrm{km} / \mathrm{h})}{4.2} \ldots \mathrm{fed} . \mathrm{h}^{-1}$

Misr J. Ag. Eng., July 2013 
Effective field capacity $=\frac{1}{\text { effective total time in hours required per feddan }} \ldots$ fed.$h^{-1}$

\section{1- Field efficiency $\left(\boldsymbol{\eta}_{\mathrm{f}}\right)$ :}

$\eta_{f}=\left(\frac{E_{f . c}}{T_{f . c}}\right) \times 100$

Where:

$\eta_{\mathrm{f}} \quad$ : field efficiency, $\%$

$\mathrm{E}_{\mathrm{f.c}} \quad$ : effective field capacity, fed/h.

$\mathrm{T}_{\text {f.c }} \quad$ : theoretical Field capacity, fed/h.

\section{2- Required engine Power (R.E.P):}

The required engine power was determined for each operation by using the following equation (Embaby, 1985).

$$
\text { R.E.P }=\left(F_{C} \times \frac{1}{3600}\right) \times \rho_{f} \times L . C . V \times 427 \times \eta_{t h} \times \eta_{m} \times \frac{1}{75} \times \frac{1}{1.36}
$$

Where:

R.E.P : Power Requirements from Fuel consumption; kW.

$\mathrm{F}_{\mathrm{c}} \quad$ : Fuel consumption rate; $\mathrm{L} / \mathrm{h}$

$\rho_{f} \quad$ : Density of the fuel; $\mathrm{kg} / \mathrm{L}$ (for diesel fuel $=0.85 \mathrm{~kg} / \mathrm{L}$ )

L.C.V : Lower calorific value of fuel $\mathrm{Kcal} / \mathrm{Kg}$; (average L.C.V of diesel fuel is $10^{4} \mathrm{kcal} / \mathrm{kg}$ )

427 : Thermo - Mechanical equivalent; $\mathrm{kg} \mathrm{m} / \mathrm{kcal}$;

$\eta_{\text {th }} \quad$ : Thermal efficiency of the engine (assumed to be $40 \%$ for diesel engine);

$\eta_{\mathrm{m}} \quad$ : Mechanical efficiency of the engine (assumed to be $80 \%$ for diesel engine).

\section{3- Specific Energy (SE):}

The specific energy $(\mathrm{kW} . \mathrm{h} / \mathrm{fed})$ for a particular operation was calculated as follows:

$$
S E=\frac{R \cdot E \cdot P}{E_{f . c}}
$$


Where:

SE : specific energy, $\mathrm{kW} . \mathrm{h} / \mathrm{fed}$.

R.E.P : power required for a particular operation, $\mathrm{kW}$,

$\mathrm{E}_{\mathrm{f.c}} \quad$ : effective field capacity, fed/h.

\section{RESULTS AND DISCUSSION}

All the obtained results are in range of the tests and for the specified soil type and soil moisture content that were mentioned in the materials and methods section, and should not be used below or above the test range and the soil conditions.

\section{1- Drawbar pull and wheel slip:}

Results presented in figs. (1 and 2 ) show the effect of traveling speed and the weight on the rear tractor wheels on the drawbar pull and wheel slip. It is obvious that both of the drawbar pull and wheel slip increased with the increase of the traveling speed. The drawbar pull and the wheel slip increased by an average (12.15 and $25.4 \%)$ and (35.89 and 58.72\%) with increasing the traveling speed (from 3.1 to $5.43 \mathrm{~km} / \mathrm{h}$ ) and (from 3.07 to $5.68 \mathrm{~km} / \mathrm{h}$ ), in case of the chisel plough and seed drill operations, respectively. Figs. (1 and 2 ) also show that the increase in drawbar pull and the decrease in wheel slip with increasing the weight on the rear tractor wheels at the given speed.

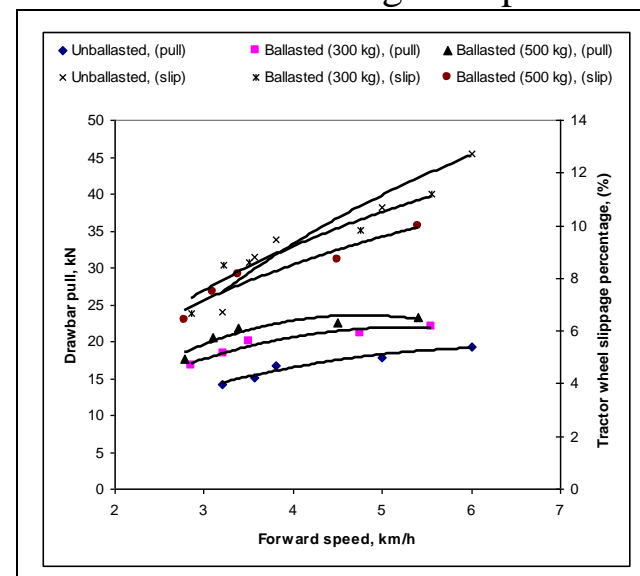

fig. (1): effect of traveling speed and different weights on drawbar pull and wheel slip during ploughing.

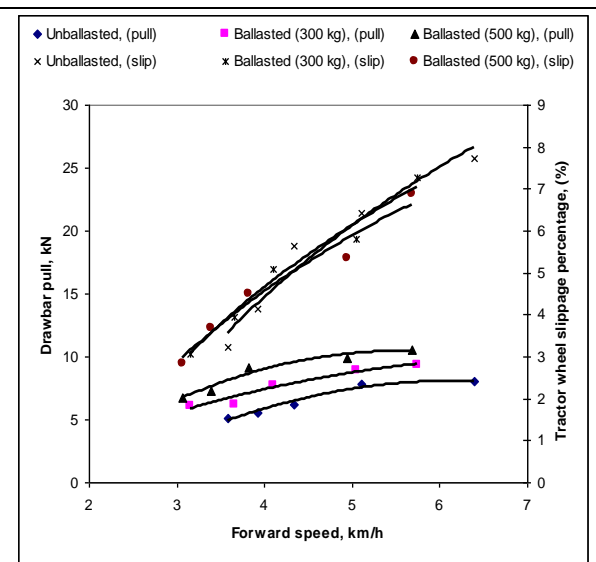

fig. (2): effect of traveling speed and different weights on drawbar pull and wheel slip during sowing. 


\section{2- Tractive efficiency}

Results illustrated in figs ( 3 and 4) show the effect of traveling speed and the weight on the rear tractor wheels on the tractive efficiency during the field operations of the chisel plough and seed drill, respectively. It is clear that the tractive efficiency decreased by increasing the traveling speed. With the use of $500 \mathrm{~kg}$ weight on the rear tractor wheels, the tractive efficiency decreased by an average $7.58 \%$ and $8.18 \%$ with the increase of the traveling speed (from 3.1 to $5.43 \mathrm{~km} / \mathrm{h}$ ) and (from 3.07 to $5.68 \mathrm{~km} / \mathrm{h}$ ), in case of the chisel plough and seed drill operations, respectively. This may be due to the losses in output power that come from both travel reduction, which is also referred to slip or pull losses. Figs. (3 and 4) also show that the increase of tractive efficiency with increasing the weight in the rear tractor wheels at the given traveling speed. This could be due to the use of the correct tire size and inflation pressure with the sufficient weight allows the tractor tires to operate at its design deflection ratio where optimum performance was obtained. Within the speed range of the tests, data showed that the highest value of the tractive efficiency, with the use of $500 \mathrm{~kg}$ weight on the rear tractor wheels, were $76 \%$ and $57.07 \%$ as the speed of 2.78 and $3.1 \mathrm{~km} / \mathrm{h}$ in case of chisel plough and seed drill operations, respectively.

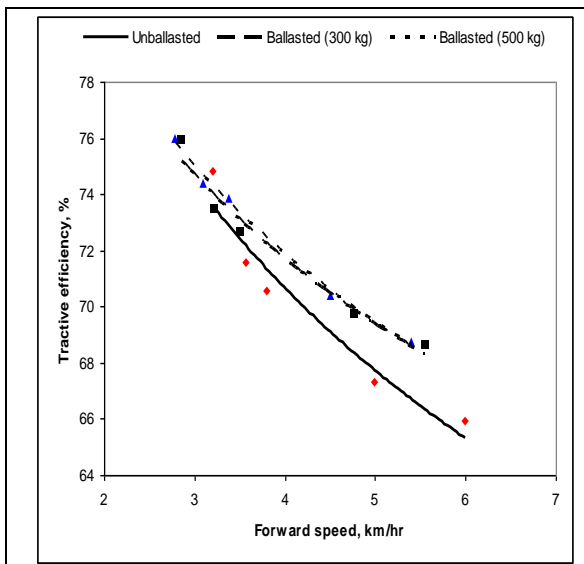

fig. (3): effect of traveling speed and different weights on tractive efficiency during ploughing.

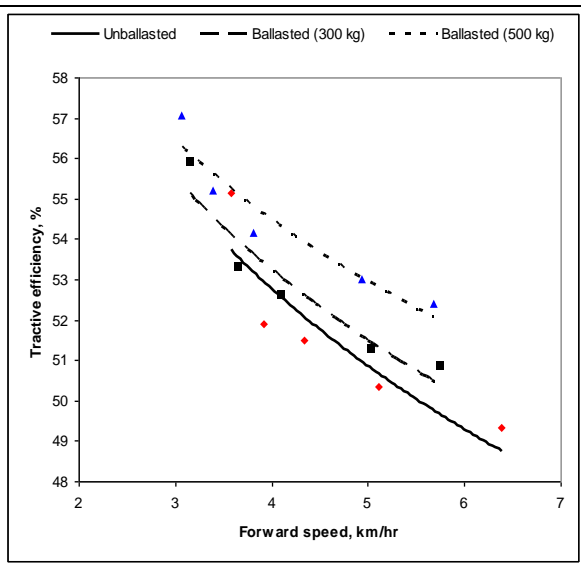

fig. (4): effect of traveling speed and different weights on tractive efficiency during sowing. 


\section{3- The effective field capacity and field efficiency:}

The relation between the travailing speed and both the effective field capacity and field efficiency of the chisel plough and seed drill operation with the use of different weights on the rear tractor wheels are presented in figs. (5 and 6). In general, the results showed that the effective filed capacity increased by increasing the traveling speed for both implements, but the field efficiency decreased with the increase of traveling speed which may be due to the increase in the theoretical field capacity. With the use of $500 \mathrm{~kg}$ weight on the rear tractor wheels and traveling speed (from 3.1 to $5.43 \mathrm{~km} / \mathrm{h}$ ) and (from 3.07 to $5.68 \mathrm{~km} / \mathrm{h}$ ), the effective field capacity increased by $44.04 \%$ and $57.52 \%$, while the field efficiency decreased by $3.76 \%$ and $3.61 \%$, in case of the chisel plough and seed drill operations, respectively. The highest value of the effective field capacity was $1.93 \mathrm{fed} / \mathrm{h}$ and $3.21 \mathrm{fed} / \mathrm{h}$ at $5.43 \mathrm{~km} / \mathrm{h}$ and $5.68 \mathrm{~km} / \mathrm{h}$ traveling speed in case of chisel plough and seed drill operations, respectively.

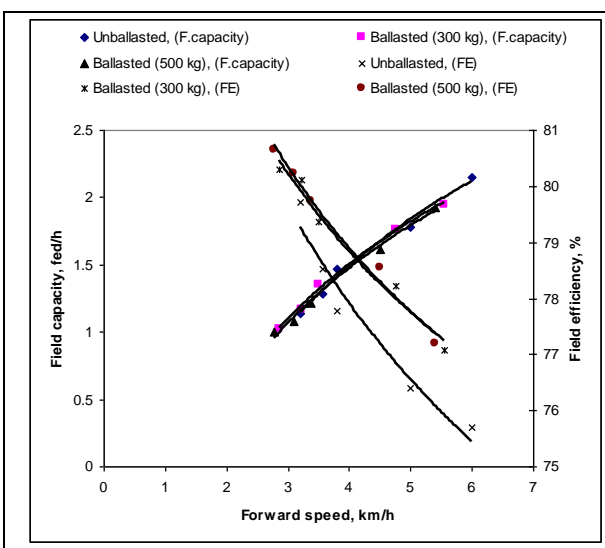

Fig. (5): effect of traveling speed and different weights on effective field capacity and field efficiency during ploughing.

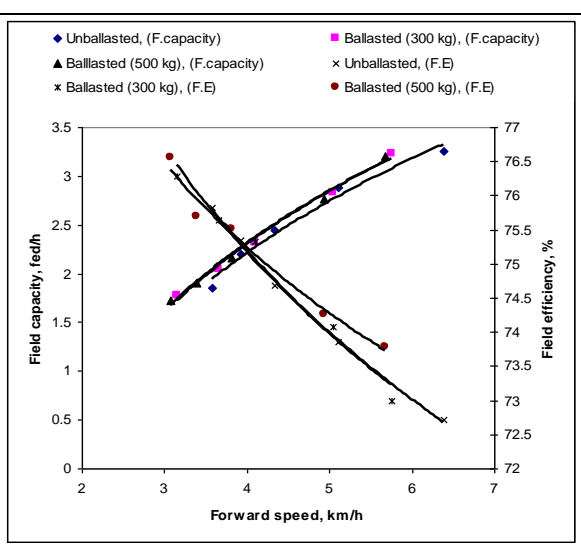

Fig. (6): effect of traveling speed and different weights on effective field capacity and field efficiency during sowing.

\section{4- Required engine power and specific energy:}

Figs. (7 and 8) show the effect of traveling speed and the weight on the rear tractor wheels on the required power $(\mathrm{kW})$ and the specific energy $(\mathrm{kWh} / \mathrm{fed})$ of the chisel plough and the seed drill operations. Its obvious 
that by increasing the traveling speed, the required power was increased, while the specific energy was decreased with the use of $500 \mathrm{~kg}$ weight on the rear tractor wheels the required power was increased by $(22.03 \%$ and $30.9 \%)$ and the specific energy was decreased by $(28.24 \%$ and $22.06 \%)$ when the traveling speed increased (from 3.1 to $5.43 \mathrm{~km} / \mathrm{h}$ ) and (from 3.07 to $5.68 \mathrm{~km} / \mathrm{h}$ ) in case of chisel plough and seed drill operation, respectively. The highest value of the required power was 59.74 and $20.65 \mathrm{~kW}$ at $(5.43$ and $5.68 \mathrm{~km} / \mathrm{h})$ traveling speed, in the mean time the specific energy was (30.95 and $6.43 \mathrm{kWh} / \mathrm{fed}$ ), in case of ploughing and sowing, respectively.

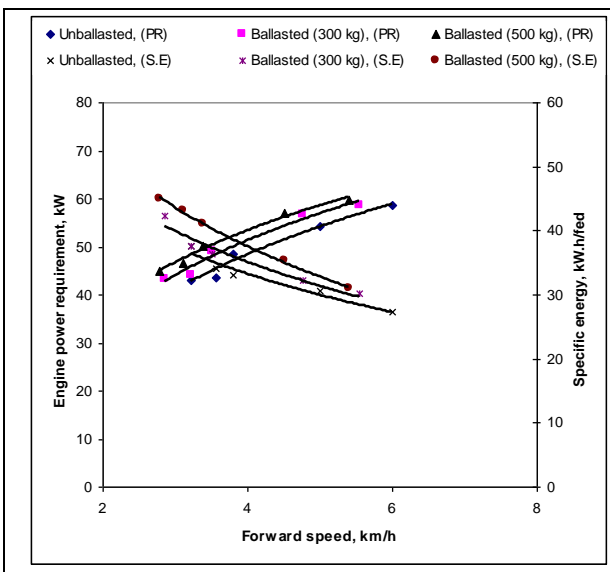

Fig. (7): effect of traveling speed and different weights on power requirement and specific energy during ploughing.

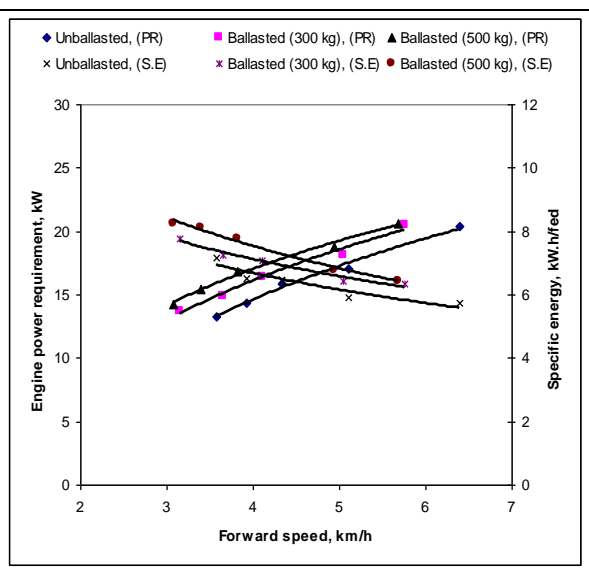

Fig. (8): effect of traveling speed and different weights on power requirement and specific energy during sowing.

\section{CONCLUSION}

The results of the present study led to the following conclusions:

1- The traveling speed and the weight on the rear tractor wheels were the most important factors that affecting the drawbar pull and the specific energy.

2- The wheel slip increased with the increase in the traveling speed, while decreased by increasing the weight on the rear tractor wheels. 
3- The drawbar pull increased by increasing the traveling speed or the weight on the rear tractor wheels.

4- The drawbar specific fuel consumption decreased with the increase in the traveling speed, or the weight on the rear tractor wheels.

5- The use of $500 \mathrm{~kg}$ weight on the tractor rear wheel at $3.1 \mathrm{~km} / \mathrm{h}$ traveling speed produced the highest value $(74.4 \%)$ of tractive efficiency, in case of chisel plough operations, and (in the mean time) the wheel slippage, filed efficiency, fuel consumption, required power, specific energy were $7.46 \%, 80.22 \%, 15.11 \mathrm{l} / \mathrm{h}, 46.58 \mathrm{~kW}$, and $43.13 \mathrm{~kW} . \mathrm{h} / \mathrm{fed}$, respectively.

6- The use of $500 \mathrm{~kg}$ weight at $3.07 \mathrm{~km} / \mathrm{h}$ traveling speed produced the highest value $(57.7 \%)$ of tractive efficiency, in case of seed drill operations, while the wheel slippage, filed efficiency, fuel consumption, required power, specific energy were $2.84 \%, 76.55 \%, 4.63 \mathrm{l} / \mathrm{h}, 14.27$ $\mathrm{kW}$, and $8.25 \mathrm{~kW} . \mathrm{h} / \mathrm{fed}$, respectively.

\section{REFERENCES}

Abbaspour-Gilandeh. Y, M. Omid and A. Keyhani, (2007). Simulation Program for Predicting Tractor Field Performance. World applied Sciences Journal 2(5): 552-558.

Abu-Hamdeh, N.II. and M.L.Al-Widyan, (1998). Effect axle load, tire inflation pressure and tillage system on soil physical properties and crop yield of a Jordanian soil. ASAE paper no.98-1060, ASAE, St. Joseph, MI 49085, USA.

Al-Ashry, A.S, (1994). Proper size of tractor in local greenhouse. Ph.D. Thesis, Fac. Agric., Kafr El-Sheikh, Tanta Univ. Egypt.

\section{Barger, E.L.; J.B. Liljedahl; W.M. Carleton and E.G. Mckibben,} (1963). Tractor and their power units. $2^{\text {nd }}$ ed., John Wiley \& Sons, New york, USA.

Bashford L.L, (1984). Power losses due to slip and motion resistance. Pp No. 84-1564, ASAE, St. Joseph, Mich, 49085, USA. 
Black, C.A., D.D. Evans J. L. White , L.E. Ensminger, and F.E. clark, (1965). Method of soil analysis (part1), physical and Mineralogical properties, including statistics of measurements and sampling, American Society of Agronomy, Inc., Publisher Madison, Wisconsin, USA. PP:357-377 and 552-557.

Dahab M.H. and H.A.E. Al-Hashem, (2002). Study on the effect of tractor power and speed on some field performance parameters working on a clay loam soil. J. Agric. Sci. Mansoura Univ., 27(1): 573-582.

El-Ashry E.R., A.I.Mohamed and A. M. Bahnasy, (2003). Effect of wheel ballast, wheel slip and inflation pressure on tractive performance, Misr.J. Agric.Eng., 20(1):PP203-222.

El-Kewey A. A. E, (1992). Effect of diameter and width of drive wheels on tractive efficiency of tractor under local conditions. M.Sc. Thesis, Fac. Of Agric Kafr El-Sheikh., Tanta Univ., Egypt.

El-Khatib. S.I, (1998). Determination and analysis of field performance of a developed cotton transplanter. Ph.D. Thesis, Fac. Agric., Ain Shams, Ain Shams Univ. Egypt.

Embaby, A. T, (1985). A comparison of the different mechanization systems for cereal crop production M. Sc. Thesis, Ag. Eng. Dep., Fac. Of Ag., Cairo Univ.

Jain S.C., and G. Philip, (2003). Farm machinery - an approach. Ist ed. Delhi: standard publishers Distributors.

Lyasko M.I, (2010). How to calculate the effect of soil conditions on tractive performance. Journal of Terramechanics , April , p 1-23.

Mehta C.R, K. Singh, and M.M. Selvan, (2010). A decision support system for selection of tractor-implement system used on Indian farms. Journal of Terramechanics: 1-9. 
Mostafa M.M., M.A. El-Gindy, M.N. Saif-Elyazal, and S.I. El-Katib, (1993). Laser land and leveling efficiency and power requirement. Misr.J. Ag.Eng (special-issue): 58-75.

Narang S and A.C Vershney, (2006). Draftability of a $8.95 \mathrm{~kW}$ walking tractor on tilled land. Journal of Terramechanics, 43:395-409.

Sahay C.S and V.K. Tewari, (2004). Computer simulation of tractor single-point drawbar performance. Biosystems Engineering 88(4): 419-428.

Sharma D. N., and S.Mukesh, (2010). "Design of agricultural tractor" (principles and problems). Published by Shri Sunil Kumar Jain for Jain Brothers (New Delhi) 16/873, East Park Road, New Delhi 110 005. First Edition, P.No: 199 - 213.

Younis S.M., R.E EL.Said, F.B. Ahmed., M.E. Islam, (2010). Development a local system for measuring tractors performance. Misr.J. Ag.Eng., January 27(1):34-53.

\section{الملخص العربي - المي}

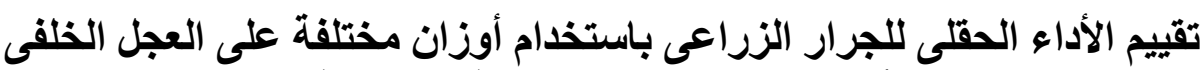

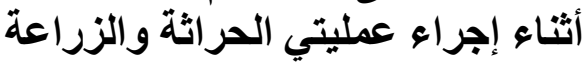

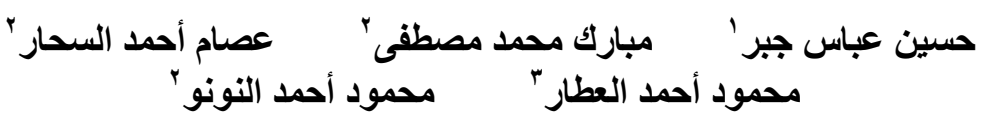

الأهداف العامة لهذه الدراسة هي التحقق من خصـائص اداء الجرار الحقلى اثنـاء اجراء عمليتي

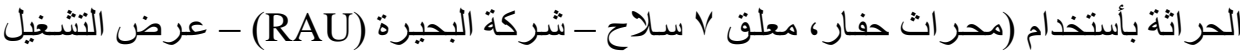

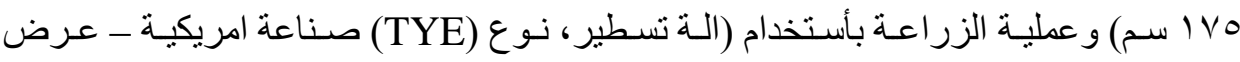

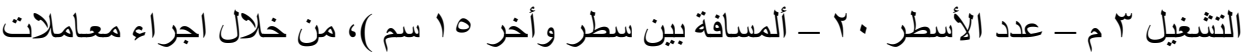

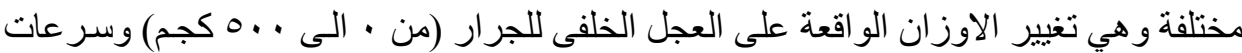

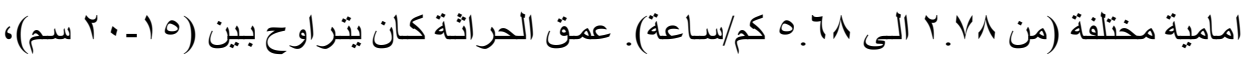

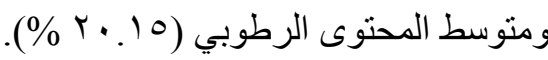

ا طالب دراسات عليا- كلية الزراعة - جامعة عين شمس.

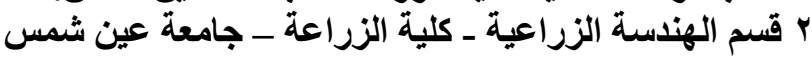

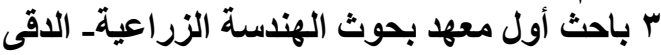




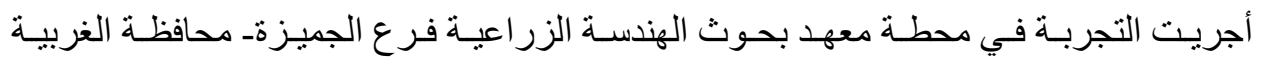

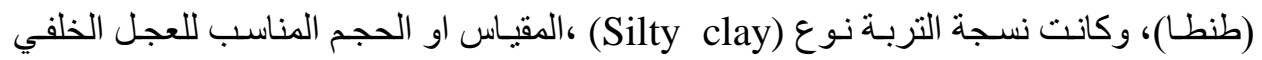

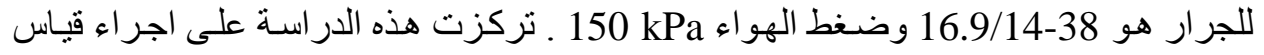

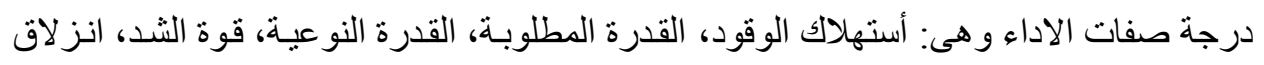
عجلة الجرار، كفاءة السحب، الأنتاجية و الكفاءة الحقلية.

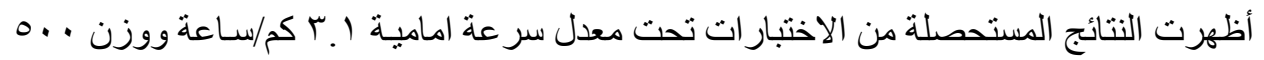

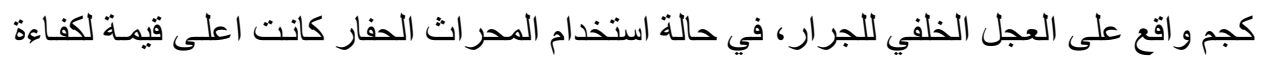

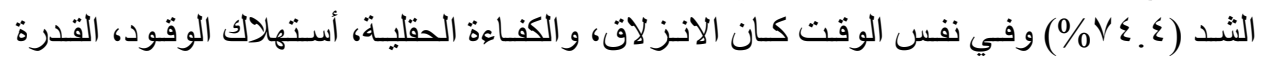

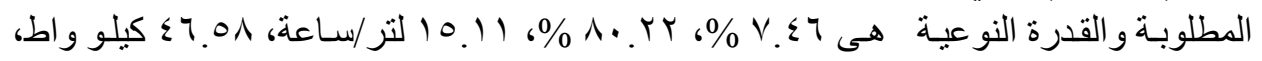

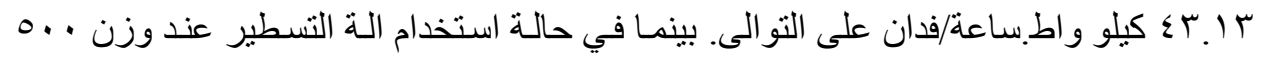

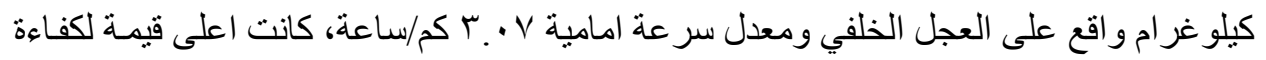

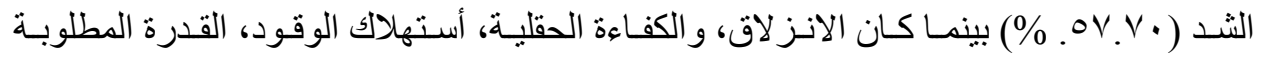

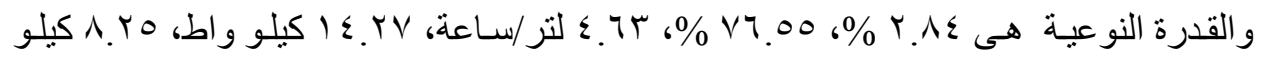

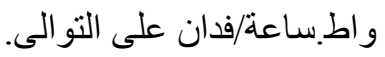
بشكل عام، السرعة الامامية للجر ار والوزن الواقع على العجل الخلفى من اكثر العو امـل المهمـة

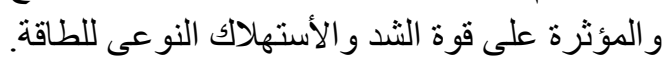

